\title{
The Debate Over Land Farming Naturally Occurring Radioactive Material (NORM) Generated by the Oil and Gas Industry in Mississippi
}

\author{
Donald J. Fournier, Jr., J. Kirby White \\ The University of Southern Mississippi
}

\begin{abstract}
Since 1995, regulators, landowners, environmental activists and the petroleum industry within the state of Mississippi have been engaged in a contentious debate over an industry-sponsored proposal to allow land farming as a disposal option for Naturally Occurring Radioactive Material (NORM) associated with the exploration and production of oil and gas. Current state regulations require that NORM associated with the exploration and production of oil and gas be disposed offsite at a licensed low level radioactive waste or NORM disposal facility, or be encapsulated and plugged in old wells meeting specified design and location criteria. The request to modify the relevant disposal rule in order to permit land farming of NORM has been met with strong opposition and legal challenges from environmental groups and affected landowners, but has recently been approved by the Mississippi State Oil and Gas Board. Further challenges in the courts are likely.

Introduction

NORM associated with the exploration and production of oil and gas in Mississippi is regulated by the Mississippi State Oil and Gas Board. Rule 69 defines NORM as "technologically enhanced naturally-occurring radioactive material consisting primarily of ${ }^{226} \mathrm{Ra}$ (and daughter radiations) and ${ }^{228} \mathrm{Ra}$ (and daughter radiations) that are derived from the exploration and production activities of oil and gas operations within the territorial area of the State of Mississippi."1 Radioactive elements which make up NORM are present in the geologic formations that bear oil and gas. When brought to the surface, these radioactive isotopes can become incorporated in pipe scale or can precipitate in sludge, creating localized concentrations of a radioactive source strong enough to require management and disposal as a radioactive waste.
\end{abstract}

In general, NORM is not restricted to oil and gas exploration and production. NORM is generated by many drilling and mining activities, including phosphate mining, metal mining, geothermal energy, coal mining, and uranium mining. NORM management and disposal is not specifically addressed by Federal regulations, however certain federal regulations do cover handling, transportation, and storage practices for NORM because it is a radioactive material. The regulation of NORM is inconsistent among different industries, and is also inconsistent from state to state. NORM associated with oil and gas exploration and production has only been found in 20 states, with the highest measurements reported in Texas, Louisiana, Florida, and Mississippi. Although NORM is produced by many drilling and mining activities, the debate in Mississippi centers on NORM within the oil and gas industry. 


\section{NORM in Scale and Sludge}

In oil and gas exploration and production, NORM is found in two forms - scale and sludge. Scale accumulates in piping and tubing, including oil flow lines, water lines, injection well tubing, production well tubing, screens, and filters. Sludge consists of dissolved solids, which precipitate within the system. The average radionuclide concentrations contained in the scale and sludge are listed in Table 1.

Table 1. Average Radionuclide Concentrations in Oil and Gas Scale and Sludge ${ }^{2}$

\begin{tabular}{|c|c|c|}
\hline Radionuclide & $\begin{array}{c}\text { Scale Concentration, } \\
\mathrm{Bq} / \mathrm{g}(\mathrm{pCi} / \mathrm{g})\end{array}$ & $\begin{array}{c}\text { Sludge Concentration, } \\
\mathrm{Bq} / \mathrm{g}(\mathrm{pCi} / \mathrm{g})\end{array}$ \\
\hline $\mathrm{Ra}-226$ & $13.3(360)$ & $2.07(56)$ \\
\hline $\mathrm{Pb}-210$ & $13.3(360)$ & $2.07(56)$ \\
\hline $\mathrm{Po}-210$ & $13.3(360)$ & $2.07(560$ \\
\hline $\mathrm{Ra}-228$ & $4.44(120)$ & $0.7(19)$ \\
\hline Th-228 & $4.44(120)$ & $0.7(19)$ \\
\hline
\end{tabular}

Regulations and Guidelines for NORM Disposal

Currently, there are no federal regulations which specifically control NORM, however USEPA has the authority to protect public health and the environment from adverse effects caused by exposure to radiation. Although they do not specifically relate to NORM, many federal statutes indirectly control various aspects of NORM handling, transportation and storage. These statutes include the Atomic Energy Act; Clean Air Act; Comprehensive Environmental Response, Compensation, and Liability Act; and Toxic Substances Control Act. The Resource Conservation and Recovery Act and the Solid Waste Disposal Act explicitly exclude source, byproduct, and special nuclear material, but they do not specifically exclude NORM.

Although there are no federal regulations that specifically control NORM, there are some state regulations, as well as state and industry guidelines, which address management and disposal of NORM generated from oil and gas exploration and production. For example, the Louisiana Department of Environmental Quality has published Regulatory Guide, Department of Environmental Quality Guidelines for Conducting NORM Confirmatory Surveys of Suspected Contamination of Land and Equipment, and Disposal of NORM Waste. ${ }^{3}$ The Texas Department of Health, Bureau of Radiation Control has published Guidelines for Conducting Close Out Surveys of Open Lands and Requesting Release for Unrestricted Use. ${ }^{4}$ The American Petroleum Institute has published Management of NORM in Oil and Gas Production. ${ }^{5}$ The Health Physics Society has published Guide for Control and Release of Naturally Occurring Radioactive Material. ${ }^{6}$ Currently, there are nine states that have developed regulations to address NORM (Table 2). 
Table 2. States with NORM Regulations ${ }^{7}$

\begin{tabular}{|c|c|c|}
\hline Arkansas & Texas & Mississippi \\
\hline Georgia & New Mexico & Oregon \\
\hline South Carolina & Louisiana & Ohio \\
\hline
\end{tabular}

Disposal options for NORM include offsite disposal at a licensed low level radioactive waste or NORM disposal facility, encapsulation in old wells meeting certain criteria, and land farming. Not all of these methods are permitted in every affected state. State and local regulations often restrict which disposal options may be used. Land farming has been used by some states in the past, but with the exception of Mississippi's new rule, is not currently permitted in any state. Land farming is defined as "a remedial action that involves blending of surface soil to ensure homogeneous distribution of NORM over the top six inches of soil." ${ }^{8}$ It represents a very cost-effective disposal method for the generator.

\section{NORM Regulations in Mississippi}

The Mississippi State Oil and Gas Board regulates NORM disposal under Rule 68. ${ }^{1}$ Rule 68 currently provides five methods for the disposal of NORM. According to the rule, acceptable methods for the disposal of NORM were limited to the following:

- $\quad$ placement between cement plugs

- $\quad$ encapsulation in pipe then placement between cement plugs

- $\quad$ mixing NORM slurry with gel or mud and placement between cement plugs

- $\quad$ placing NORM slurry into a formation

- $\quad$ offsite disposal at a licensed low level radioactive waste or NORM disposal facility

After four years of rule development and court battles, the Mississippi State Oil and Gas Board adopted a modification to Rule 68 on November 30, 1999, which will permit land farming of NORM generated by the oil and gas industry. Once the rule has been submitted to the secretary of state's office, it will become effective in 60 days. The Board has engaged consultants, heard testimony from experts and conducted public hearings regarding the use of land farming for disposal of low level NORM adjacent to well sites. The proposed rule has been challenged in court where expert testimony has been rendered on both sides of the issue. The proposal created controversy between landowners and environmental activists on one hand and the oil and gas industry on the other.

The proposal is controversial for many reasons. Although it is risk-based, it allows oil and gas companies with a lease to spread NORM adjacent to the well location without regard to the landowner. The rule proposed by industry was based on six basic elements: ${ }^{8}$

- $\quad$ regulations should control "real" rather than "perceived" threats to human health

- $\quad$ NORM should be clearly defined for regulatory purposes

- $\quad$ the Mississippi State Oil and Gas Board should administer a NORM regulation program

- $\quad$ regulations must be consistent with existing radiation protection standards

- $\quad$ a risk-based approach to regulation should be implemented 
- $\quad$ regulations must be implementable by those who are subject to its provisions

In trial testimony, industry experts testified that the rule insures exposure of less than 100 millirem Total Effective Dose Equivalent per year, whereas a conservative estimate of exposure rates that could cause adverse health effects is 10,000-20,000 millirem per year. Industry experts also reported that because "oil field NORM" is in the form of an insoluble sulfate, the radium is not very soluble in body fluids and minimally transportable throughout the environment via stormwater runoff, dissolution and percolation to groundwater, or uptake by plants and animals. Industry proponents see passage of this rule modification as a milestone because it is the first regulation in the United States promulgated to deal exclusively with NORM from oil and gas exploration and production. It is the first risk-based NORM radiation regulation, and will be easily implementable by regulated parties. ${ }^{8}$

Opponents to the proposed rule include affected landowners and environmental groups. They are concerned about health affects, reduced property value and uncertain long-term environmental impacts. The newly approved modification to Rule 68 has been appealed by opponents to land farming as a disposal option for NORM.

Bibliography

1. Mississippi State Oil and Gas Board. Statutes: Rules of Procedure Statewide Rules and Regulations (1996).

2. Diffuse NORM Wastes - Waste Characterization and Preliminary Risk Assessment. Prepared by S. Cohen and Associates, Inc., and Rogers \& Associates Engineering Corp., for the U.S. Environmental Protection Agency Office of Radiation and Air (1993).

3. Regulatory Guide, Department of Environmental Quality Guidelines for Conducting NORM Confirmatory Surveys of Suspected Contamination of Land and Equipment, and Disposal of NORM Waste. Louisiana Department of Environmental Quality (1990).

4. Guidelines for Conducting Close Out Surveys of Open Lands and Requesting Release for Unrestricted Use. Regulatory Guide 5.10. Texas Department of Health, Bureau of Radiation Control, Austin, Texas (1990).

5. Bulletin E2 on Management of Naturally Occurring Radioactive Materials. G11005. American Petroleum Institute, Washington, D.C. (1993).

6. Health Physics Society. Guide for Control and Release of Naturally Occurring Radioactive Material. Working Draft - January 1997. Health Physics Society, McLean, Virginia (1997).

7. URL: http://www.normis.com

8. Berger and Kelly. Position Paper. Integrated Environmental Management (1996).

DONALD J. FOURNIER, JR.

Don Fournier is an Assistant Professor in the School of Engineering Technology at The University of Southern Mississippi. Mr. Fournier is a registered Professional Engineer and has ten years of industrial experience, primarily related to R\&D, pollution control, combustion, and safety. Mr. Fournier received B.S. and M.S. degrees in Mechanical Engineering from the University of Florida in 1986 and 1988, respectively.

\section{J. KIRBY WHITE}

J. Kirby White is a graduate student studying Environmental Compliance and Safety Technology in the School of Engineering Technology at the University of Southern Mississippi. He received his B.S. in Psychology from the University of Southern Mississippi in 1998 and studied Workforce Training and Development as an undergraduate student prior to enrolling in graduate school. 